CARDIOVASCULAR MEDICINE

\title{
National survey of the prevalence, incidence, primary care burden, and treatment of heart failure in Scotland
}

\author{
N F Murphy, C R Simpson, F A McAlister, S Stewart, K Maclntyre, M Kirkpatrick, J Chalmers, \\ A Redpath, S Capewell, J J V McMurray
}

Heart 2004;90:1129-1136. doi: 10.1136/hrt.2003.029553

See end of article for
authors' affiliations
........................
Correspondence to:
Professor John J V
McMurray, Department of
Cardiology, Western
Infirmary, Glasgow,
G11 6NT, UK;
i.mcmurray@bio.gla.ac.uk

Accepted 5 February 2004

\begin{abstract}
Objective: To examine the epidemiology, primary care burden, and treatment of heart failure in Scotland, UK.

Design: Cross sectional data from primary care practices participating in the Scottish continuous morbidity recording scheme between 1 April 1999 and 31 March 2000.

Setting: 53 primary care practices (307 741 patients).

Subjects: 2186 adult patients with heart failure.

Results: The prevalence of heart failure in Scotland was 7.1 in 1000, increasing with age to 90.1 in 1000 among patients $\geqslant 85$ years. The incidence of heart failure was 2.0 in 1000 , increasing with age to 22.4 in 1000 among patients $\geqslant 85$ years. For older patients, consultation rates for heart failure equalled or exceeded those for angina and hypertension. Respiratory tract infection was the most common comorbidity leading to consultation. Among men, $23 \%$ were prescribed a $\beta$ blocker, $11 \%$ spironolactone, and $46 \%$ an angiotensin converting enzyme inhibitor. The corresponding figures for women were $20 \%$ $(p=0.29$ versus men), $7 \%(p=0.02)$, and $34 \%(p<0.001)$. Among patients $<75$ years $26 \%$ were prescribed a $\beta$ blocker, $11 \%$ spironolactone, and $50 \%$ an angiotensin converting enzyme inhibitor. The corresponding figures for patients $\geqslant 75$ years were $19 \%(p=0.04$ versus patients $<75), 7 \%$ $(p=0.04)$, and $33 \%(p<0.001)$.

Conclusions: Heart failure is a common condition, especially with advancing age. In the elderly, the community burden of heart failure is at least as great as that of angina or hypertension. The high rate of concomitant respiratory tract infection emphasises the need for strategies to immunise patients with heart failure against influenza and pneumococcal infection. Drugs proven to improve survival in heart failure are used less frequently for elderly patients and women.
\end{abstract}

$\mathrm{T}$ hough heart failure is perceived to be one of the most common, disabling, costly, and deadly cardiovascular disorders encountered in clinical practice, its epidemiology and the burden it places on health care systems are still poorly defined, especially in primary care. ${ }^{1-3}$ In particular, incidence studies are lacking. Similarly, the other problems with which patients with heart failure consult general practitioners have not been reported. There are also no comparisons of the community burden of heart failure with other common cardiovascular disorders. Lastly, there are few contemporary data on the treatment of heart failure in primary care across a whole country. ${ }^{4}$

The Scottish continuous morbidity recording (CMR) in general practice scheme prospectively collects detailed information from a number of general practices ( 53 at the time of this study with 307741 patients), broadly representative of the whole Scottish population in terms of age, sex, socioeconomic status, and rural-urban mix. ${ }^{5}$ This scheme therefore allows accurate estimates of the national prevalence, incidence, consultation rates, concomitant medical problems, and drug treatment for patients with heart failure in primary care.

We have therefore used the Scottish CMR scheme to give a more comprehensive picture of the national epidemiology and primary care burden of heart failure than has been obtained by existing studies.

\section{METHODS}

The CMR collects data from general practitioners in Scotland. At the time of this study, 53 practices participated in CMR covering 6\% of the Scottish population. Any computerised general practice can volunteer to take part in CMR. Practices are weighted to form a national sample that is broadly representative of the Scottish population as a whole in terms of age, sex, deprivation, and urban-rural mix.

As previously described, general practices participating in the CMR scheme collect data from every face to face doctorpatient contact. ${ }^{5-7}$ All contacts with practice patients (including temporary residents) are captured and recorded by every doctor (including locums). Up to 10 problems can be recorded for each contact and doctors are asked to describe the problem as specifically in diagnostic terms as possible. Each diagnosis is given a Read code along with an appropriate "modifier" of "first", "recurrent", or "persistent" to denote whether the problem is new, a recurrence of a previous problem, or a continuing problem, respectively. ${ }^{8}$ The data are entered on to the General Practice Administration System for Scotland computer system and an extract is sent every month on floppy disc for analysis. The Information and Statistics Division of the Common Services Agency of the NHS in Scotland has a quality insurance programme for the CMR scheme. This involves a rolling programme of practice visits to compare CMR data with practice held records: the completeness of contact capture was $91 \%$ and the accuracy of Read coding was $91 \%$ in 1999/2000 (L Graham, personal communication, 29 November 2003).

Abbreviations: $A C E$, angiotensin converting enzyme; $A R B$, angiotensin receptor blocker; CMR, continuous morbidity recording; EPICA, epidemiologia da insuficiěncia cardiaca a aprendizagen; NHÁNES, national health and nutrition examination survey; $O R$, odds ratio 
To estimate period prevalence, all patients who had a consultation generating a heart failure related Read code from 1 April 1999 to 31 March 2000 were included. Any patient who died or moved away from the practice before 31 March 2000 was excluded. Patients not attending their general practitioner during the year of the study were also not accounted for. While this may have led to an underestimate of prevalence, it is unlikely that many patients with heart failure would not attend their general practitioner within a 12 month period.

The incidence was estimated by including all patients with a Read code for heart failure during the period 1 April 1999 to 31 March 2000 that had a modifier of "first".

The contact rate was derived from the total number of consultations divided by attendances ("contacts") occurring over the year of the study.

As the CMR practices are representative of the Scottish population, the CMR data were used to estimate prevalence, incidence, and contact rates for the whole Scottish population on an age and sex specific basis.

Repeat prescription data were obtained for a representative subset of the "period prevalence" group, so as to describe which medications these patients took on a regular basis. Newly started medication (that is, where a second prescription had not been issued) was not accounted for. The prescription rates reported may, therefore, slightly underestimate the true rate of use of the drugs concerned.

Postcodes of residence were used to assign a Carstairs deprivation category from 1 (least deprived) to 7 (most deprived) to each person. These categories are derived from 1991 census data on the proportion of residents who are unemployed, live in overcrowded accommodation, do not have a car, or belong to a low occupational social class. ${ }^{9}$

For comparative purposes, contact rates for other common cardiovascular conditions (hypertension and angina) are also described. We examined where heart failure ranks among all reasons for consultation with a general practitioner. ${ }^{10}$

For these analyses, the denominator was the total registered practice population from April 1999 to March 2000 (except for prescription data, where the denominator was the subset in which these data were available).

We compared prescribing data between men and women and between age group categories by $\chi^{2}$ tests. We performed multivariate logistic regression to examine the independent effects of age, sex, deprivation category, and general practitioner on prescribing of heart failure medications.

\section{RESULTS}

\section{Heart failure Read codes used}

Contacts were coded as congestive heart failure (51.0\%), left ventricular failure $(23.6 \%)$, heart failure-not otherwise specified $(10.0 \%)$, heart failure $(6.7 \%)$, acute left ventricular failure $(4.1 \%)$, acute congestive heart failure $(3.7 \%)$, chronic congestive heart failure (1.2\%), compensated cardiac failure $(0.5 \%)$, or acute heart failure $(0.1 \%)$.

\section{Prevalence of heart failure}

Table 1 shows the one year CMR prevalence for men and women of differing ages with heart failure. Prevalence was extremely low among patients aged $<45$ years, increased sixfold between the age ranges $45-64$ years and $65-74$ years, and more than doubled again between the age ranges $65-74$ years and 75-84 years. The prevalence of heart failure was higher among women (7.8/1000) than in men (6.4/1000). Extrapolating from the CMR practices to the whole of the country, the estimated number of Scots with heart failure in 2000 was, therefore, 37305 (16 216 men), 87\% of whom were aged $\geqslant 65$ years and $60 \%$ of whom were $\geqslant 75$ years (table 2).

\section{Incidence of heart failure}

Table 1 shows the one year incidence for men and women of differing ages with heart failure. This was extremely low in patients aged $<45$ years, increased fourfold to fivefold between the age ranges 45-64 years and 65-74 years, and increased again twofold to threefold between the age ranges 65-74 years and 75-84 years. The incidence of heart failure was higher among women $(2.2 / 1000)$ than men (1.8/1000). The estimated number of Scots presenting with heart failure for the first time in the year 2000 was, therefore, 10375 ( 4504 men), $84 \%$ of whom were aged $\geqslant 65$ years and $58 \%$ of whom were $\geqslant 75$ years (table 2 ).

\section{Contact rates for heart failure}

The one year contact rate was extremely low among patients aged $<45$ years, increased almost sevenfold between the age ranges $45-64$ years and 65-74 years, and nearly trebled again between the age ranges 65-74 years and 75-84 years (table 1). The contact rate for heart failure was higher among women (17.9/1000) than men (16.5/1000).

Overall, contact rates were approximately two to three times higher than prevalence for both men and women. The average number of contacts for each patient with heart failure was 2.6 for men and 2.3 for women. The average number of contacts for each patient doubled between the youngest and oldest subgroups among men (from 1.4 for patients $<45$ years to 2.8 for patients $\geqslant 85$ years) and almost doubled among women ( $1.4 \vee 2.5)$.

\section{General practitioner contact rates for heart failure compared with hypertension, angina, and other conditions}

For comparison, contact rates for hypertension and angina were 96.2 in 1000 and 21.2 in 1000, respectively, for men and 133.9 in 1000 and 19.2 in 1000, respectively, for women. Figure 1 shows age specific contact rates for men and fig 2 for women for hypertension, angina, and heart failure. In older age groups, consultation rates for heart failure equalled or exceeded those for both hypertension and, especially, angina. Table 3 shows the most common conditions leading to contact with a general practitioner for men and women in different age groups. Heart failure was one of the top five reasons for consultation for men aged $\geqslant 75$ years and for women $\geqslant 85$ years.

\section{Concomitant diagnoses among patients with heart failure}

Table 4 snows the top 10 concomitant diagnostic codings among patients consulting with heart failure. For both sexes, lower respiratory tract infection was the most common concomitant diagnostic coding (28\% of men and women). Coronary or ischaemic heart disease was the second most frequently coded, reported by $22 \%$ of men and $13 \%$ of women. A concomitant coding for hypertension was recorded for $14 \%$ of men and $16 \%$ of women, and $12 \%$ of men and $10 \%$ of women had a coding for atrial fibrillation (atrial fibrillation was not one of the top 10 concomitantly coded conditions for women with heart failure). The frequency of other diagnoses was generally similar for men and women.

\section{Medications taken by patients with heart failure}

Prescribing information was available from 22 CMR practices with a combined list size of 140246 patients $(2.6 \%$ of the Scottish population). The age range, sex distribution, and level of deprivation of these patients were comparable with those of the total Scottish population. Tables 5, 6, and 7 show the medications prescribed for patients with heart failure, stratified by sex and age. Diuretics were prescribed for $81 \%$ of these patients, angiotensin converting enzyme (ACE) 
Table 1 Contact rates, incidence, and prevalence per 1000 population by sex and age group for all CMR practices in Scotland, April 1999-March 2000

\begin{tabular}{|c|c|c|c|c|c|c|c|c|}
\hline & $\begin{array}{l}\text { Age group } \\
\text { (years) }\end{array}$ & Population & $\begin{array}{l}\text { Number of } \\
\text { patients with HF }\end{array}$ & $\begin{array}{l}\text { Prevalence } \\
(/ 1000)\end{array}$ & $\begin{array}{l}\text { Number of first HF } \\
\text { diagnoses }\end{array}$ & $\begin{array}{l}\text { First ever } \\
\text { incidence } \\
(/ 1000)\end{array}$ & $\begin{array}{l}\text { Number of } \\
\text { contacts for HF }\end{array}$ & $\begin{array}{l}\text { Contact rate } \\
(/ 1000)\end{array}$ \\
\hline \multirow[t]{7}{*}{ Men } & $45-64$ & 37990 & 163 & 4.3 & 52 & 1.4 & 378 & 9.9 \\
\hline & $65-74$ & 11446 & 294 & 25.7 & 69 & 6.0 & 745 & 65.1 \\
\hline & $75-84$ & 5802 & 371 & 63.9 & 117 & 20.2 & 994 & 171.3 \\
\hline & $\geqslant 85$ & 1290 & 134 & 103.9 & 32 & 24.8 & 372 & 288.4 \\
\hline & $\geqslant 65$ & 18538 & 799 & 43.1 & 218 & 11.8 & 2111 & 113.9 \\
\hline & $\geqslant 75$ & 7092 & 505 & 71.2 & 149 & 21.0 & 1366 & 192.6 \\
\hline & All ages & 152033 & 973 & 6.4 & 271 & 1.8 & 2504 & 16.5 \\
\hline \multirow[t]{7}{*}{ Women } & $45-64$ & 37356 & 120 & 3.2 & 48 & 1.3 & 247 & 6.6 \\
\hline & $65-74$ & 13428 & 278 & 20.7 & 82 & 6.1 & 587 & 43.7 \\
\hline & $75-84$ & 9408 & 500 & 53.1 & 127 & 13.5 & 1174 & 124.8 \\
\hline & $\geqslant 85$ & 3617 & 308 & 85.2 & 78 & 21.6 & 763 & 210.9 \\
\hline & $\geqslant 65$ & 26453 & 1086 & 41.1 & 287 & 10.9 & 2524 & 95.4 \\
\hline & $\geqslant 75$ & 13025 & 808 & 62.0 & 205 & 15.7 & 1937 & 148.7 \\
\hline & All ages & 155708 & 1213 & 7.8 & 338 & 2.2 & 2,781 & 17.9 \\
\hline \multirow[t]{7}{*}{ Both sexes } & $45-64$ & 75346 & 283 & 3.8 & 100 & 1.3 & 625 & 8.3 \\
\hline & $65-74$ & 24874 & 572 & 23.0 & 151 & 6.1 & 1332 & 53.5 \\
\hline & $75-84$ & 15210 & 871 & 57.3 & 244 & 16.0 & 2168 & 142.5 \\
\hline & $\geqslant 85$ & 4907 & 442 & 90.1 & 110 & 22.4 & 1135 & 231.3 \\
\hline & $\geqslant 65$ & 44991 & 1885 & 41.9 & 505 & 11.2 & 4635 & 103.0 \\
\hline & $\geqslant 75$ & 20117 & 1313 & 65.3 & 354 & 17.6 & 3303 & 164.2 \\
\hline & All ages & 307741 & 2186 & 7.1 & 609 & 2.0 & 5285 & 17.2 \\
\hline
\end{tabular}

$\mathrm{CMR}$, continuous morbidity recording; $\mathrm{HF}$, heart failure.

There were 18 patients $(11$ men) aged $\leqslant 44$ years with heart failure, four with a first diagnosis (one man). These patients made 25 contacts ( 15 men). The CMR practice population $<45$ years is 187404 (95505 men).

inhibitors for $39 \%$, $\beta$ blockers for $21 \%$, digoxin for $21 \%$, and spironolactone for $9 \%$. Only $11 \%$ of these patients were prescribed both an ACE inhibitor and a $\beta$ blocker, and $1 \%$ were prescribed the combination of ACE inhibitor, $\beta$ blocker, and spironolactone.

There were significant sex differences in prescribing. Eighty per cent of men were prescribed a diuretic, $46 \%$ an ACE inhibitor, $23 \%$ a $\beta$ blocker, $11 \%$ spironolactone, and $24 \%$ digoxin. The corresponding figures for women were $81 \%$ $(\mathrm{p}=0.87 v$ men $), 34 \%(\mathrm{p}<0.001), 20 \%(\mathrm{p}=0.29), 7 \%$ $(\mathrm{p}=0.02)$, and $18 \%(\mathrm{p}=0.02)$, respectively. There were also significant age differences, with $50 \%$ of patients $<75$ years, but only $33 \%$ of patients $\geqslant 75$, prescribed an ACE inhibitor $(\mathrm{p}<0.001)$. Twenty six per cent of patients $<75$ years and $19 \%$ of patients $\geqslant 75$ years were prescribed a $\beta$ blocker $(p=0.04)$. These proportions for spironolactone were $11 \%$ and $7 \%$, respectively $(p=0.04)$. There was no difference in the rate of use of digoxin.

There was a clear association between age and sex (more older patients were women) and multivariate analyses showed that age was the most important factor influencing prescribing patterns. Indeed, sex was only significantly associated with ACE inhibitor prescribing (men were $42 \%$ more likely $(p=0.009)$ to be prescribed an ACE inhibitor

Table 2 Estimated number of contacts, first diagnoses, and patients by sex and age group and percentages of totals for Scotland, * April 1999-March 2000

\begin{tabular}{|c|c|c|c|c|c|c|c|}
\hline & $\begin{array}{l}\text { Age group } \\
\text { (years) }\end{array}$ & $\begin{array}{l}\text { Number of } \\
\text { patients with HF }\end{array}$ & $\begin{array}{l}\% \text { of total } \\
\text { patients with HF }\end{array}$ & $\begin{array}{l}\text { Number of first } \\
\text { diagnoses for HF }\end{array}$ & $\begin{array}{l}\% \text { of total first } \\
\text { diagnoses for HF }\end{array}$ & $\begin{array}{l}\text { Number of } \\
\text { contacts for HF }\end{array}$ & $\begin{array}{l}\% \text { of total } \\
\text { contacts for HF }\end{array}$ \\
\hline \multirow[t]{8}{*}{ Men } & $0-44$ & 183 & 1.1 & 17 & 0.4 & 249 & 0.6 \\
\hline & $45-64$ & 2510 & 15.5 & 801 & 17.8 & 5820 & 13.9 \\
\hline & $65-74$ & 5041 & 31.1 & 1183 & 26.3 & 12775 & 30.6 \\
\hline & $75-84$ & 6238 & 38.5 & 1967 & 43.7 & 16713 & 40.0 \\
\hline & $\geqslant 85$ & 2244 & 13.8 & 536 & 11.9 & 6231 & 14.9 \\
\hline & $\geqslant 65$ & 13523 & 83.4 & 3686 & 81.8 & 35719 & 85.5 \\
\hline & $\geqslant 75$ & 8482 & 52.3 & 2503 & 55.6 & 22944 & 54.9 \\
\hline & All ages & 16216 & NA & 4504 & NA & 41788 & NA \\
\hline \multirow{8}{*}{ Women } & $0-44$ & 118 & 0.6 & 51 & 0.9 & 168 & 0.3 \\
\hline & $45-64$ & 1979 & 9.4 & 792 & 13.5 & 4073 & 8.4 \\
\hline & $65-74$ & 5046 & 23.9 & 1489 & 25.4 & 10656 & 22.1 \\
\hline & $75-84$ & 8743 & 41.5 & 2221 & 37.8 & 20529 & 42.5 \\
\hline & $\geqslant 85$ & 5203 & 24.7 & 1318 & 22.4 & 12888 & 26.7 \\
\hline & $\geqslant 65$ & 18992 & 90.1 & 5028 & 85.6 & 44073 & 91.2 \\
\hline & $\geqslant 75$ & 13946 & 66.1 & 3539 & 60.3 & 33417 & 69.2 \\
\hline & All ages & 21089 & NA & 5871 & NA & 48314 & NA \\
\hline \multirow[t]{8}{*}{ Both sexes } & $0-44$ & 301 & 0.8 & 68 & 0.7 & 417 & 0.5 \\
\hline & $45-64$ & 4489 & 12.0 & 1593 & 15.4 & 9893 & 11.0 \\
\hline & $65-74$ & 10087 & 27.0 & 2672 & 25.8 & 23431 & 26.0 \\
\hline & $75-84$ & 37242 & 41.3 & 4188 & 40.4 & 37242 & 41.3 \\
\hline & $\geqslant 85$ & 7447 & 20.0 & 1854 & 17.9 & 19119 & 21.2 \\
\hline & $\geqslant 65$ & 32515 & 87.2 & 8714 & 84.0 & 79792 & 88.6 \\
\hline & $\geqslant 75$ & 22428 & 60.1 & 6042 & 58.2 & 56361 & 62.6 \\
\hline & All ages & 37305 & NA & 10375 & NA & 90102 & NA \\
\hline
\end{tabular}




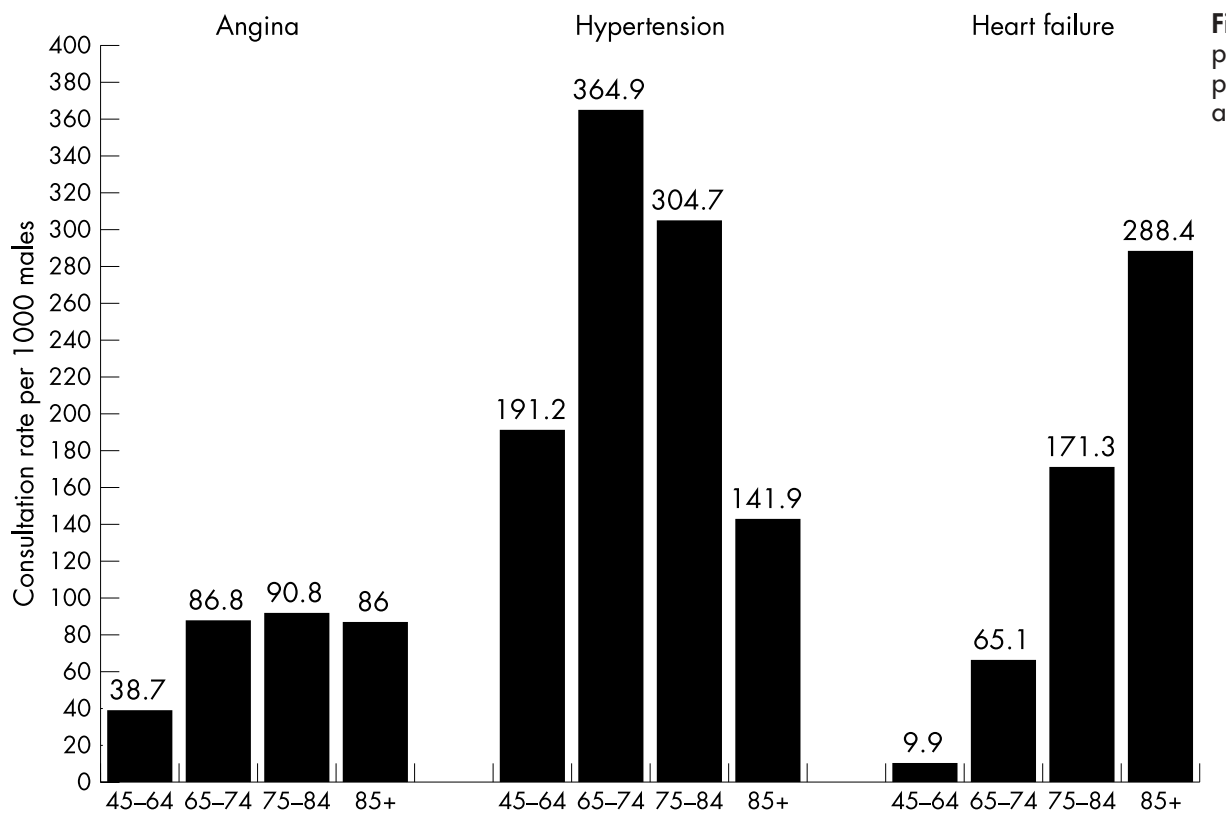

than women, even after adjusting for age). The multivariate analyses showed that, compared with patients $<65$ years, older patients were less likely to be prescribed ACE inhibitors (odds ratio (OR) 0.60 for patients aged 75-84 years $(p<0.001)$ and OR 0.39 for patients $\geqslant 85$ years $(p<0.001))$ or the combination of ACE inhibitors plus $\beta$ blockers (OR 0.60 for patients aged 75-84 years $(\mathrm{p}=0.03)$ and OR 0.32 for patients $\geqslant 85$ years $(\mathrm{p}=0.001))$.

\section{DISCUSSION}

This study has a number of important strengths. Not only does it describe the prevalence and incidence of heart failure across a whole country but it also describes overall contact rates with general practitioners. Furthermore, we report comparative contact rates for other common cardiovascular (and non-cardiovascular) conditions. Finally, we also describe the contemporary pharmacological treatment of heart failure in primary care.
A number of recent prevalence studies in the UK have focused on the presence of echocardiographic left ventricular systolic dysfunction and not a clinical diagnosis of heart failure per se. ${ }^{11-13}$ The first of these, from Glasgow, was limited in concentrating on a relatively young age group (1640 patients aged 45-74), when heart failure is known to be uncommon before the age of 70 years (as confirmed in the present study). ${ }^{11}$ The second report from Poole in England examined 817 patients aged 70-84 years. ${ }^{12}$ Another more recent survey examined 3960 patients $\geqslant 45$ years, but, like the former studies, was limited to a single urban area (the West Midlands of England). ${ }^{13}$ Other studies in the UK have usually involved only a small number (one to three) of general practices or relied on diuretic prescription as a surrogate for heart failure. ${ }^{14-17}$ Recording of concomitant medical problems, concomitant drug treatment, and the frequency and nature of contacts (surgery or office visits, home visits, out of hours visits) has been limited or absent. ${ }^{14-17}$

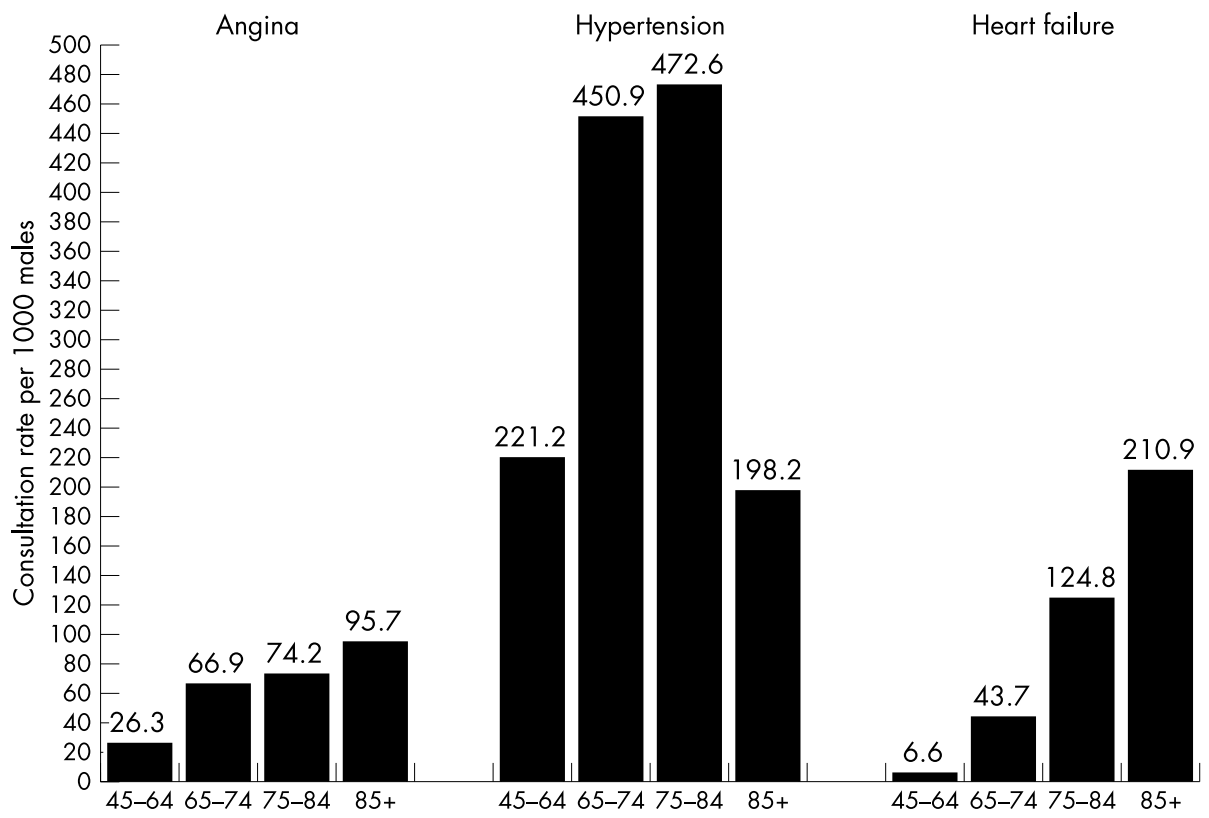

Figure 2 Age stratified general practitioner consultation rates per 1000 population for heart failure, angina, and hypertension for women. 
Table 3 The five most common reasons for consulting a general practitioner in Scotland by sex and age group in 2000*

\begin{tabular}{|c|c|c|c|c|c|c|c|c|}
\hline & \multicolumn{4}{|l|}{ Men } & \multicolumn{4}{|l|}{ Women } \\
\hline & 45-64 years & $65-74$ years & $75-84$ years & $\geqslant 85$ years & 45-64 years & $65-74$ years & $75-84$ years & $\geqslant 85$ years \\
\hline Hypertension & 1 (229) & $1(445)$ & $1(386)$ & $4(155)$ & $3(269)$ & $1(572)$ & $1(565)$ & $1(242)$ \\
\hline Back problems & $2(148)$ & NA & NA & NA & $4(177)$ & $3(150)$ & $4(169)$ & NA \\
\hline Depression & $3(125)$ & NA & NA & NA & $2(275)$ & $4(148)$ & NA & NA \\
\hline Lower RTI & $4(88)$ & $2(175)$ & $2(216)$ & $1(290)$ & NA & $2(189)$ & $2(216)$ & $2(240)$ \\
\hline Anxiety & $5(73)$ & NA & NA & NA & $5(160)$ & NA & NA & NA \\
\hline Coronary heart disease & NA & $3(156)$ & $5(125)$ & NA & NA & NA & NA & NA \\
\hline COPD & NA & 4 (147) & 3 (198) & $3(160)$ & NA & NA & NA & NA \\
\hline Diabetes mellitus & NA & $5(143)$ & NA & NA & NA & NA & NA & NA \\
\hline Heart failure & NA & NA & $4(136)$ & $2(248)$ & NA & NA & NA & $5(169)$ \\
\hline Menopause & NA & NA & NA & NA & $1(313)$ & NA & NA & NA \\
\hline Osteoarthritis & NA & NA & NA & NA & NA & $5(143)$ & $3(186)$ & NA \\
\hline Urinary tract infection & NA & NA & NA & NA & NA & NA & 5 (147) & NA \\
\hline Dementia & NA & NA & NA & NA & NA & NA & NA & $3(215)$ \\
\hline General miscellaneous & NA & NA & NA & $5(154)$ & NA & NA & NA & $4(185)$ \\
\hline
\end{tabular}

It is difficult to precisely compare our findings with prior studies, as many of these did not include both sexes or the whole population age range. Nevertheless, with respect to men aged $0-74$ years, our prevalence $(0.32 \%)$ was very close to that found in the Rochester epidemiology project $(0.33 \%) .{ }^{18} 19$ The proportions for women were $0.28 \%$ in Scotland and $0.21 \%$ in Rochester. The NHANES (national health and nutrition examination survey) investigators reported a prevalence of $1.1 \%$ among men and $1.0 \%$ among women aged $25-74$ years in the USA. ${ }^{20}$ Our prevalence among men aged $45-74$ years was $0.92 \%$ and $0.78 \%$ among women. We also had reasonably close agreement with another north European study, the Rotterdam study, which reported a prevalence of $3.4 \%$ in patients aged 65-84 years ${ }^{21}$ (compared with $3.6 \%$ in the same age group in our study). On the other hand, a study from Copenhagen reported that the prevalence of heart failure signs and symptoms in three general practices was $6.4 \%$ among patients $>50$ years. This is much higher than the prevalence in our study $(1.8 \%$ among patients $>45$ years).22

Another national primary care survey from southern Europe also reported discrepant findings. The EPICA (epidemiologia da insuficiěncia cardiaca a aprendizagen) investigators reported a prevalence of heart failure among men aged $>25$ years of $4.33 \%$. The prevalence among women was $4.38 \% .^{23}$

The deficiencies in existing epidemiological investigations of heart failure are even more apparent when it comes to incidence studies, with only one Finnish, two UK, and one US study reported until recently. ${ }^{24-28}$ The Finnish and American studies were confined to a limited geographical area (four rural communities in eastern Finland and Olmsted County in Minnesota). ${ }^{24-26}$ Of the two UK studies, one was hospital based, was limited to part of London, and adopted an unusually broad definition of heart failure (including heart failure arising as a complication during hospitalisation with an acute coronary syndrome). ${ }^{27}$ The second study used data from the UK general practice research database to describe the incidence of newly diagnosed heart failure during 1996. ${ }^{28}$ That study did not, however, describe pharmacological treatment.

The incidence of heart failure in the Scottish population was 1.8 in 1000 in men and 2.2 in 1000 in women, and this figure is in keeping with the previous estimates from the UK (1.4 and 1.2/1000), ${ }^{27}$ Finland (1.0 and 4.0/1000), ${ }^{24}$ and the USA (3.4 and 2.4/1000). ${ }^{26}$

What appears to be different, at first sight, between the prior studies and ours is the higher overall prevalence and incidence of heart failure among women than among men. This, however, reflects the wider age range included in our study, compared with most others, and the predominance of women over men with heart failure in the very elderly segment of the population. ${ }^{29} 30$

The lack of information on contact rates in primary care has been a surprising gap in the literature on heart failure. ${ }^{31}$ We found that the contact rate is two to three times the

Table 4 Proportion of patients with HF seen with a specified condition or illness, April 1999-March 2000*

\begin{tabular}{lll}
\hline Condition/illness & Men $(\mathbf{n = 9 7 3 )}$ & Women $(\mathbf{n}=1213)$ \\
\hline Lower RTI & $273(28.1 \%)$ & $338(27.9 \%)$ \\
Coronary heart disease-miscellaneous & $216(22.2 \%)$ & $159(13.1 \%)$ \\
Breathlessness & $201(20.7 \%)$ & $247(20.4 \%)$ \\
Angina & $144(14.8 \%)$ & $141(11.6 \%)$ \\
COPD & $142(14.6 \%)$ & NA \\
Upper RTI (excluding sore throat) & $141(14.5 \%)$ & $176(14.5 \%)$ \\
Hypertension & $134(13.8 \%)$ & $196(16.2 \%)$ \\
Atrial flutter/fibrillation & $114(11.7 \%)$ & NA \\
Oedema & $111(11.4 \%)$ & $177(14.6 \%)$ \\
Miscellaneous & $108(11.1 \%)$ & $144(11.9 \%)$ \\
Back problems & NA & $153(12.6 \%)$ \\
Osteoarthritis & NA & $143(11.8 \%)$ \\
\hline *Number (per cent). & & \\
NA, not applicable. & & \\
\hline
\end{tabular}


Table 5 Pharmacological treatment of men with heart failure (HF) in Scotland, April 1999-March 2000

\begin{tabular}{|c|c|c|c|c|c|c|c|}
\hline \multirow[b]{2}{*}{ Treatment } & \multicolumn{7}{|c|}{ Age group (years) } \\
\hline & $45-64$ & $65-74$ & $75-84$ & $\geqslant 85$ & $<75$ & $\geqslant 75$ & All ages \\
\hline Number & 64 & 132 & 164 & 74 & 201 & 238 & 439 \\
\hline Furosemide & $\begin{array}{l}36 \\
(56.3 \%)\end{array}$ & $\begin{array}{l}80 \\
(60.3 \%)\end{array}$ & $\begin{array}{l}114 \\
(69.5 \%)\end{array}$ & $\begin{array}{l}49 \\
(66.2 \%)\end{array}$ & $\begin{array}{l}119 \\
(59.2 \%)\end{array}$ & $\begin{array}{l}163 \\
(68.5 \%)\end{array}$ & $\begin{array}{l}282 \\
(64.2 \%)\end{array}$ \\
\hline Any diuretic & $\begin{array}{l}47 \\
(73.4 \%)\end{array}$ & $\begin{array}{l}105 \\
(79.6 \%)\end{array}$ & $\begin{array}{l}139 \\
(84.8 \%)\end{array}$ & $\begin{array}{l}58 \\
(78.4 \%)\end{array}$ & $\begin{array}{l}155 \\
(77.1 \%)\end{array}$ & $\begin{array}{l}197 \\
(82.8 \%)\end{array}$ & $\begin{array}{l}352 \\
(80.2 \%)\end{array}$ \\
\hline ACE inhibitor & $\begin{array}{l}39 \\
(60.9 \%)\end{array}$ & $\begin{array}{l}71 \\
(53.8 \%)\end{array}$ & $\begin{array}{l}69 \\
(42.1 \%)\end{array}$ & $\begin{array}{l}21 \\
(28.4 \%)\end{array}$ & $\begin{array}{l}111 \\
(55.2 \%)\end{array}$ & $\begin{array}{l}90 \\
(37.8 \%)\end{array}$ & $\begin{array}{l}201 \\
(45.8 \%)\end{array}$ \\
\hline ARB & $\begin{array}{l}4 \\
(6.3 \%)\end{array}$ & $\begin{array}{l}5 \\
(3.8 \%)\end{array}$ & $\begin{array}{l}8 \\
(4.9 \%)\end{array}$ & $\begin{array}{l}1 \\
(1.4 \%)\end{array}$ & 9 & $\begin{array}{l}9 \\
(3.8 \%)\end{array}$ & $\begin{array}{l}18 \\
(4.1 \%)\end{array}$ \\
\hline$\beta$ Blocker & $\begin{array}{l}20 \\
(31.3 \%)\end{array}$ & $\begin{array}{l}34 \\
(25.8 \%)\end{array}$ & $\begin{array}{l}33 \\
(20.1 \%)\end{array}$ & $\begin{array}{l}14 \\
(18.9 \%)\end{array}$ & $\begin{array}{l}55 \\
(27.4 \%)\end{array}$ & $\begin{array}{l}47 \\
(19.8 \%)\end{array}$ & $\begin{array}{l}102 \\
(23.2 \%)\end{array}$ \\
\hline Spironolactone & $\begin{array}{l}12 \\
(18.8 \%)\end{array}$ & $\begin{array}{l}16 \\
(12.1 \%)\end{array}$ & $\begin{array}{l}16 \\
(9.8 \%)\end{array}$ & $\begin{array}{l}4 \\
(5.4 \%)\end{array}$ & $\begin{array}{l}28 \\
(13.9 \%)\end{array}$ & $\begin{array}{l}20 \\
(8.4 \%)\end{array}$ & $\begin{array}{l}48 \\
(10.9 \%)\end{array}$ \\
\hline Digoxin & $\begin{array}{l}17 \\
(26.6 \%)\end{array}$ & $\begin{array}{l}30 \\
(22.7 \%)\end{array}$ & $\begin{array}{l}43 \\
(26.2 \%)\end{array}$ & $\begin{array}{l}15 \\
(20.3 \%)\end{array}$ & $\begin{array}{l}47 \\
(23.4 \%)\end{array}$ & $\begin{array}{l}58 \\
(24.4 \%)\end{array}$ & $\begin{array}{l}105 \\
(23.9 \%)\end{array}$ \\
\hline Any HF treatment & $\begin{array}{l}57 \\
(89.1 \%)\end{array}$ & $\begin{array}{l}114 \\
(86.4 \%)\end{array}$ & $\begin{array}{l}149 \\
(90.9 \%)\end{array}$ & $\begin{array}{l}61 \\
(82.4 \%)\end{array}$ & $\begin{array}{l}175 \\
\text { (87.1\%) }\end{array}$ & $\begin{array}{l}210 \\
(88.2 \%)\end{array}$ & $\begin{array}{l}385 \\
(87.7 \%)\end{array}$ \\
\hline
\end{tabular}

prevalence-that is, patients average two to three heart failure related contacts each year with their general practitioner. This rate was remarkably consistent between men and women and across all age groups.

Not only are there few data on the rates of consultation with general practitioners but there is also little information on the reasons for consultation. ${ }^{32}{ }^{33}$ We found that lower respiratory tract infection was the single most common problem recorded by general practitioners for both men and women with heart failure. The potential importance of this is suggested by the knowledge that pulmonary infection is a commonly recorded precipitant of heart failure hospitalisation. ${ }^{34}{ }^{35}$ These two observations underscore the importance of influenza and pneumococcal immunisations for patients with heart failure. ${ }^{36}{ }^{37}$ The other major co-morbidities reflect the most common causes of heart failure (coronary artery disease and hypertension), other smoking related illnesses (such as chronic obstructive pulmonary disease), and degenerative diseases of aging (back problems, osteoarthritis).

Another gap in our knowledge has been how the primary care burden of heart failure compares with that of other cardiovascular and non-cardiovascular conditions. ${ }^{32} 33$
Consultation rates for heart failure were much lower than those for angina and, especially, hypertension for patients $<75$ years. Thereafter, heart failure consultation rates exceeded those for angina and by the age of $\geqslant 85$ exceeded those for hypertension also. It is interesting to speculate that the falling prevalence and consultation rates for hypertension and angina, relative to heart failure, in the older age groups may reflect the natural history of coronary heart disease and hypertension progressing to heart failure over time.

Another important feature of this study is the description of the contemporary pharmacological management of heart failure in primary care across a whole country. Though, as expected, most patients had been prescribed a diuretic, there was a striking age differential in the prescription of evidenced based treatments: older patients were significantly less likely to be prescribed ACE inhibitors, $\beta$ blockers, or spironolactone. There are several possible explanations for these observations. The above treatments are indicated when left ventricular systolic function is reduced and not when it is preserved. Heart failure in the elderly is more often associated with preserved left ventricular systolic function. ${ }^{30}$ Digoxin, however, was used at least as commonly in the elderly, yet is also indicated only when left ventricular systolic function is

Table 6 Pharmacological treatment of women with heart failure (HF) in Scotland, April 1999-March 2000

\begin{tabular}{|c|c|c|c|c|c|c|c|}
\hline \multirow[b]{2}{*}{ Treatment } & \multicolumn{7}{|c|}{ Age group (years) } \\
\hline & $45-64$ & $65-74$ & $75-84$ & $>85$ & $<75$ & $\geqslant 75$ & All ages \\
\hline Number & 56 & 116 & 227 & 166 & 176 & 393 & 569 \\
\hline Furosemide & $\begin{array}{l}30 \\
(53.6 \%)\end{array}$ & $\begin{array}{l}66 \\
(56.9 \%)\end{array}$ & $\begin{array}{l}124 \\
(54.6 \%)\end{array}$ & $\begin{array}{l}97 \\
(58.4 \%)\end{array}$ & $\begin{array}{l}97 \\
(55.1 \%)\end{array}$ & $\begin{array}{l}221 \\
(56.2 \%)\end{array}$ & $\begin{array}{l}318 \\
(55.9 \%)\end{array}$ \\
\hline Any diuretic & $\begin{array}{l}42 \\
(75.0 \%)\end{array}$ & $\begin{array}{l}95 \\
(81.9 \%)\end{array}$ & $\begin{array}{l}190 \\
(83.7 \%)\end{array}$ & $\begin{array}{l}132 \\
(79.5 \%)\end{array}$ & $\begin{array}{l}138 \\
(78.4 \%)\end{array}$ & $\begin{array}{l}322 \\
(81.9 \%)\end{array}$ & $\begin{array}{l}460 \\
(80.8 \%)\end{array}$ \\
\hline ACE inhibitor & $\begin{array}{l}24 \\
(42.9 \%)\end{array}$ & $\begin{array}{l}53 \\
(45.7 \%)\end{array}$ & $\begin{array}{l}76 \\
(33.5 \%)\end{array}$ & $\begin{array}{l}41 \\
(24.7 \%)\end{array}$ & $\begin{array}{l}77 \\
(43.8 \%)\end{array}$ & $\begin{array}{l}117 \\
(29.8 \%)\end{array}$ & $\begin{array}{l}194 \\
(34.1 \%)\end{array}$ \\
\hline ARB & $\begin{array}{l}5 \\
(8.9 \%)\end{array}$ & $\begin{array}{l}5 \\
(4.3 \%)\end{array}$ & $\begin{array}{l}14 \\
(6.2 \%)\end{array}$ & $\begin{array}{l}6 \\
(3.6 \%)\end{array}$ & $\begin{array}{l}10 \\
(5.7 \%)\end{array}$ & $\begin{array}{l}20 \\
(5.1 \%)\end{array}$ & $\begin{array}{l}30 \\
(5.3 \%)\end{array}$ \\
\hline$\beta$ Blocker & $\begin{array}{l}14 \\
(25.0 \%)\end{array}$ & $\begin{array}{l}27 \\
(23.3 \%)\end{array}$ & $\begin{array}{l}51 \\
(22.5 \%)\end{array}$ & $\begin{array}{l}22 \\
(13.3 \%)\end{array}$ & $\begin{array}{l}41 \\
(23.3 \%)\end{array}$ & $\begin{array}{l}73 \\
(18.6 \%)\end{array}$ & $\begin{array}{l}114 \\
(20.0 \%)\end{array}$ \\
\hline Spironolactone & $\begin{array}{l}3 \\
(5.4 \%)\end{array}$ & $\begin{array}{l}10 \\
(8.6 \%)\end{array}$ & $\begin{array}{l}13 \\
(5.7 \%)\end{array}$ & $\begin{array}{l}12 \\
(7.2 \%)\end{array}$ & $\begin{array}{l}13 \\
(7.4 \%)\end{array}$ & $\begin{array}{l}25 \\
(6.4 \%)\end{array}$ & $\begin{array}{l}38 \\
(6.7 \%)\end{array}$ \\
\hline Digoxin & $\begin{array}{l}6 \\
(10.7 \%)\end{array}$ & $\begin{array}{l}18 \\
(15.5 \%)\end{array}$ & $\begin{array}{l}43 \\
(18.9 \%)\end{array}$ & $\begin{array}{l}35 \\
(21.1 \%)\end{array}$ & $\begin{array}{l}25 \\
(14.2 \%)\end{array}$ & $\begin{array}{l}78 \\
(19.8 \%)\end{array}$ & $\begin{array}{l}103 \\
(18.1 \%)\end{array}$ \\
\hline Any HF treatment & $\begin{array}{l}49 \\
(87.5 \%)\end{array}$ & $\begin{array}{l}102 \\
(87.9 \%)\end{array}$ & $\begin{array}{l}206 \\
(90.7 \%)\end{array}$ & $\begin{array}{l}139 \\
(83.7 \%)\end{array}$ & $\begin{array}{l}153 \\
(86.9 \%)\end{array}$ & $\begin{array}{l}345 \\
(87.8 \%)\end{array}$ & $\begin{array}{l}498 \\
(87.5 \%)\end{array}$ \\
\hline
\end{tabular}


Table 7 Pharmacological treatment of men and women with heart failure (HF) in Scotland, April 1999-March 2000

\begin{tabular}{llllllll}
\hline \multirow{2}{*}{ Treatment } & \multicolumn{2}{l}{ Age group (years) } & & & & & \\
\cline { 2 - 8 } & $\mathbf{4 5 - 6 4}$ & $\mathbf{6 5 - 7 4}$ & $\mathbf{7 5 - 8 4}$ & $>\mathbf{8 5}$ & $<\mathbf{7 5}$ & $\geqslant \mathbf{7 5}$ & All ages \\
\hline Number & 120 & 248 & 391 & 240 & 377 & 631 & 1008 \\
Furosemide & 66 & 146 & 238 & 146 & 216 & 384 & 600 \\
& $(55.0 \%)$ & $(58.9 \%)$ & $(60.9 \%)$ & $(60.8 \%)$ & $(57.3 \%)$ & $(60.9 \%)$ & $(59.5 \%)$ \\
Any diuretic & 89 & 200 & 329 & 190 & 293 & 519 & 812 \\
& $(74.2 \%)$ & $(80.7 \%)$ & $(84.1 \%)$ & $(79.2 \%)$ & $(77.7 \%)$ & $(82.3 \%)$ & $(80.6 \%)$ \\
ACE inhibitor & 63 & 124 & 145 & 62 & 188 & 207 & 395 \\
& $(52.5 \%)$ & $(50.0 \%)$ & $(37.1 \%)$ & $(25.8 \%)$ & $(49.9 \%)$ & $(32.8 \%)$ & $(39.2 \%)$ \\
ARB & 9 & 10 & 22 & 7 & 19 & 29 & 48 \\
& $(7.5 \%)$ & $(4.0 \%)$ & $(5.6 \%)$ & $(2.9 \%)$ & $(5.0 \%)$ & $(4.6 \%)$ & $(4.8 \%)$ \\
$\beta$ Blocker & 34 & 61 & 84 & 36 & 96 & 120 & 216 \\
& $(28.3 \%)$ & $(24.6 \%)$ & $(21.5 \%)$ & $(15.0 \%)$ & $(25.5 \%)$ & $(19.0 \%)$ & $(21.4 \%)$ \\
Spironolactone & 15 & 26 & 29 & 16 & 41 & 45 & 86 \\
& $(12.5 \%)$ & $(10.5 \%)$ & $(7.4 \%)$ & $(6.9 \%)$ & $(10.9 \%)$ & $(7.1 \%)$ & $(8.5 \%)$ \\
Digoxin & 23 & 48 & 86 & 50 & 72 & 136 & 208 \\
& $(19.2 \%)$ & $(19.4 \%)$ & $(22.0 \%)$ & $(20.8 \%)$ & $(19.1 \%)$ & $(21.6 \%)$ & $(20.6 \%)$ \\
Any HF treatment & 106 & 216 & 355 & 200 & 328 & 555 & 883 \\
& $(88.3 \%)$ & $(87.1 \%)$ & $(90.8 \%)$ & $(83.3 \%)$ & $(87.0 \%)$ & $(87.9 \%)$ & $(87.6 \%)$ \\
\hline
\end{tabular}

reduced. Perhaps ACE inhibitors, $\beta$ blockers, and spironolactone have a perceived or real contraindication more often among the elderly or are not as well tolerated by the elderly. ${ }^{30}$ The other possibility is that these treatments are not offered to the elderly as often as they are to younger patients, as has been reported for other conditions. ${ }^{38}$ The concern that older patients with heart failure may be inappropriately denied treatments proven to reduce morbidity and mortality is worthy of further investigation. Women also received less evidence based treatment and this was not wholly explained by the generally older average age of women. Preserved left ventricular systolic function is also more common among women and this may explain at least part of the sex difference in treatment. ${ }^{29}{ }^{30}$ Women may also tolerate these other treatments less well and there is some evidence that this is true for ACE inhibitors. ${ }^{29}{ }^{39}$ Curiously, however, the greatest sex difference in evidence based prescribing was for spironolactone, which should be better tolerated by women than men. This again raises the concern, as in other disease areas, that women are undertreated compared with men. ${ }^{40}$

As in any study of this type, there are limitations. One is the lack of information on cardiac structure and function, which did not allow us to differentiate between patients with reduced and preserved left ventricular systolic function. Nevertheless, we have been able to provide information on the community burden of the syndrome of heart failure, rather than left ventricular systolic dysfunction, which has been the main focus of most other epidemiological studies. Secondly, we do not have any independent confirmation of heart failure diagnoses or data on disease severity.

In summary, this study confirms that heart failure is predominantly a problem of the elderly. When the full age spectrum is accounted for, there are more women than men with heart failure in the population. In the elderly, heart failure is one of the most common causes of consultation with a general practitioner and is at least as common a cause of consultation as angina and hypertension. Patients consult on average two to three times a year. Respiratory tract infection is the most common co-morbidity leading to consultation in primary care. There is a notable age discrepancy in prescribing of evidence based treatment, with the elderly receiving less life saving treatment. There is also an independent sex effect with women also receiving less evidence based treatment. These discrepancies merit further investigation.

\section{Authors' affiliations}

N F Murphy, J J V McMurray, Department of Cardiology, Western Infirmary, Glasgow, UK

C R Simpson, Department of General Practice and Primary Care, University of Aberdeen, Aberdeen, UK

F A McAlister, Department of Medicine, University of Alberta, Edmonton, Alberta, Canada

S Stewart, Division of Health Sciences, University of South Australia, Adelaide, South Australia, Australia

K Maclntyre, Department of Public Health, University of Glasgow, Glasgow, UK

M Kirkpatrick, J Chalmers, A Redpath, Information and Statistics Division, Trinity Park House, Edinburgh, UK

S Capewell, Department of Public Health, University of Liverpool, Liverpool, UK

\section{REFERENCES}

1 Cowie MR, Mosterd A, Wood DA, et al. The epidemiology of heart failure. Eur Heart J 1997; 18:208-25.

2 Redfield MM. Epidemiology and pathophysiology of heart failure. Curr Cardiol Rep 2000;2:179-80.

3 McMurray JJ, Stewart S. Epidemiology, aetiology, and prognosis of heart failure. Heart 2000;83:596-602.

4 Cleland JG, Cohen-Solal A, Aguilar JC, et al. Management of heart failure in primary care (the improvement of heart failure programme): an international survey. Lancet 2002;360:1631-9.

5 Milne RM, Taylor MW, Taylor RJ. Audit of populations in general practice: the creation of a national resource for the study of morbidity in Scottish general practice. J Epidemiol Community Health 1998;52:20S-4S

6 Kyaw MH, Wayne B, Chalmers J, et al. Influenza and pneumococcal vaccine distribution and use in primary care and hospital settings in Scotland coverage, practice and policies. Epidemiol Infect 2002;128:445-55.

7 Pears E, Hannaford PC, Taylor MW. Gender, age and deprivation differences in the primary care management of hypertension in Scotland: a cross-sectional database study. Fam Pract 2003;20:22-31.

8 O'Neil M, Payne C, Read J. Read codes version 3: a user led terminology. Methods Inf Med 1995;34:187-92.

9 Carstairs V, Morris R. Deprivation and health in Scotland. Aberdeen: Aberdeen University Press, 1991.

10 Anon. Practice team information. 13 August 2003. www.show.scot.nhs.uk/ isd/cmr (accessed 18 March 2004)

11 McDonagh TA, Morrison CE, Lawrence A, et al. Symptomatic and asymptomatic left-ventricular systolic dysfunction in an urban population. Lancet 1997;350:829-33.

12 Morgan S, Smith H, Simpson I, et al. Prevalence and clinical characteristics of left ventricular dysfunction among elderly patients in general practice setting: cross sectional survey. BMJ 1999;318:368-72.

13 Davies M, Hobbs F, Davis R, et al. Prevalence of left-ventricular systolic dysfunction and heart failure in the echocardiographic heart of England screening study: a population based study. Lancet 2001;358:439-44.

14 Parameshwar J, Shackell MM, Richardson A, et al. Prevalence of heart failure in three general practices in north west London. Br J Gen Pract 1992;42:287-9. 
15 Clarke KW, Gray D, Hampton JR. How common is heart failure? Evidence from PACT (prescribing analysis and cost) data in Nottingham. J Public Health Med 1995; 17:459-64.

16 Mair FS, Crowley TS, Bundred PE. Prevalence, aetiology and management of heart failure in general practice. Br J Gen Pract 1996:46:77-9.

17 Lip G, Sawer S, Ahmed I, et al. A survey of heart failure in general practice. Eur J Gen Pract 1997;3:85-9.

18 Rodeheffer RJ, Jacobsen SJ, Gersh BJ, et al. The incidence and prevalence of congestive heart failure in Rochester, Minnesota. Mayo Clin Proc 1993:68:1143-50.

19 Redfield MM, Jacobsen SJ, Burnett JC Jr, et al. Burden of systolic and diastolic ventricular dysfunction in the community: appreciating the scope of the heart failure epidemic. JAMA 2003;289:194-202.

20 Schocken DD, Arrieta MI, Leaverton PE, et al. Prevalence and mortality rate of congestive heart failure in the United States. J Am Coll Cardiol 1992;20:301-6.

21 Mosterd A, Hoes AW, de Bruyne MC, et al. Prevalence of heart failure and left ventricular dysfunction in the general population: the Rotterdam study. Eur Heart J 1999;20:447-55.

22 Nielsen OW, Hilden J, Larsen CT, et al. Cross sectional study estimating prevalence of heart failure and left ventricular systolic dysfunction in community patients at risk. Heart 2001;86:172-8.

23 Ceia $F$, Fonseca $C$, Mota T, et al. Prevalence of chronic heart failure in southwestern Europe: the EPICA study. EPICA Investigators. Eur J Heart Fail 2002;4:531-9.

24 Remes J, Reunanen A, Aromaa A, et al. Incidence of heart failure in eastern Finland: a population-based surveillance study. Eur Heart J 1992;13:588-93.

25 Senni M, Tribouilloy CM, Rodeheffer RJ, et al. Congestive heart failure in the community: a study of all incident cases in Olmsted County, Minnesota, in 1991. Circulation 1998;98:2282-9.

26 Senni M, Tribouilloy CM, Rodeheffer RJ, et al. Congestive heart failure in the community: trends in incidence and survival in a 10-year period. Arch Intern Med 1999;159:29-34

27 Cowie MR, Wood DA, Coats AJ, et al. Incidence and aetiology of heart failure: a population-based study. Eur Heart J 1999;20:421-8.
28 Johansson S, Wallander MA, Ruigomez A, et al. Incidence of newly diagnosed heart failure in UK general practice. Eur J Heart Fail $2001 ; 3: 225-31$.

29 Petrie MC, Dawson NF, Murdoch DR, et al. Failure of women's hearts. Circulation 1999:99:2334-41.

30 Petrie MC, Berry C, Stewart S, et al. Failing ageing hearts. Eur Heart $J$ $2001 ; 22: 1978-90$.

31 Wheeldon NM, MacDonald TM, Flucker CJ, et al. Echocardiography in chronic heart failure in the community. Q J Med 1993;86:17-23.

32 Lien CT, Gillespie ND, Struthers AD, et al. Heart failure in frail elderly patients: diagnostic difficulties, co-morbidities, polypharmacy and treatment dilemmas. Eur J Heart Fail 2002:4:91-8.

33 Havranek EP, Masoudi FA, Westfall KA, et al. Spectrum of heart failure in older patients: results from the national heart failure project. Am Heart $J$ 2002;143:412-7.

34 Chin MH, Goldman L. Factors contributing to the hospitalization of patients with congestive heart failure. Am J Public Health 1997;87:643-8.

35 Stewart S, Mclntyre K, Capewell S, et al. Heart failure in a cold climate: seasonal variation in heart failure-related morbidity and mortality. J Am Coll Cardiol 2002;39:760-6.

36 Nichol KL, Margolis KL, Wuorenma J, et al. The efficacy and cost effectiveness of vaccination against influenza among elderly persons living in the community. N Engl J Med 1994;331:778-84.

37 Nichol KL, Wuorenma J, von Sternberg T. Benefits of influenza vaccination for low-, intermediate-, and high-risk senior citizens. Arch Intern Med 1998; 158:1769-76.

38 Bowling A. Ageism in cardiology. BMJ 1999;319:1353-5.

39 Shah MR, Granger CB, Bart BA, et al. Sex-related differences in the use and adverse effects of angiotensin-converting enzyme inhibitors in heart failure: the study of patients intolerant of converting enzyme inhibitors registry. Am J Med 2000;109:489-92.

40 Sheifer SE, Escarce JJ, Schulman KA. Race and sex differences in the management of coronary artery disease. Am Heart $J$ 2000;139:848-57.

\section{IMAGES IN CARDIOLOGY}

\section{Severe left ventricular hypertrophy in Anderson-Fabry disease}

A 45 year old asymptomatic man was referred with hypertension and pronounced electrographic left ventricular hypertrophy (LVH), strikingly confirmed by TrueFISP cardiac magnetic resonance (CMR) imaging (panels $\mathrm{A}-\mathrm{C}$ ). Gross, concentric LVH (septal thickness $3 \mathrm{~cm}$ ) without outflow tract obstruction or valvopathy was evident. The serum creatinine was elevated, and urinalysis revealed proteinuria. The differential diagnosis included hypertension with end organ manifestations, and hypertrophic cardiomyopathy (HCM). However, a renal biopsy revealed Anderson-Fabry disease (AFD).

AFD is a rare $X$ linked recessive disorder, resulting in a deficiency of the enzyme, $\alpha$-galactosidase $\mathrm{A}$, with subsequent glycosphingolipid accumulation. In classical AFD serum galactosidase concentrations are undetectable. Enzyme activity may also be reduced in female carriers, in whom cardiac complications also occur. A variant form, predominantly affecting the heart, is also recognised. The enzyme concentration was severely reduced in this patient.

In subjects with LVH, appearances on echo or CMR imaging may be reminiscent of HCM, although outflow tract obstruction is unusual. AFD was the underlying cause in $4 \%$ of middle aged

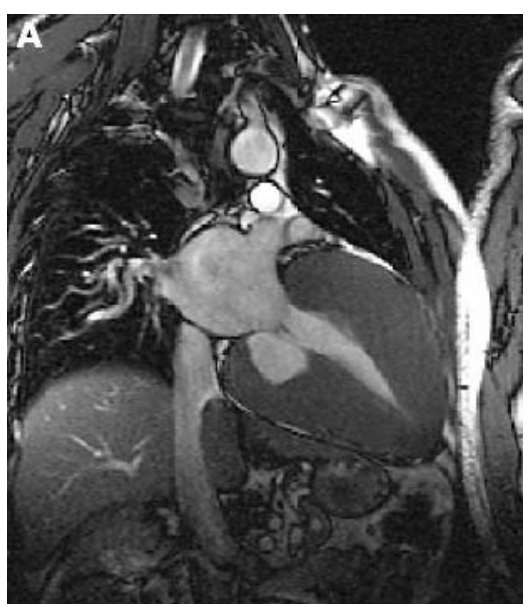

subjects with apparent HCM in one study. Gadolinium enhanced CMR imaging may be of potential value in distinguishing AFD cardiomyopathy from HCM. Enzyme replacement therapy has reduced left ventricular mass in AFD. As cardiomyopathy in AFD may be reversible, this condition should be excluded in cases of unexplained LVH.

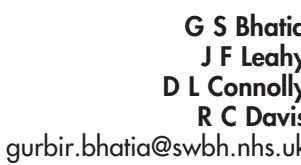

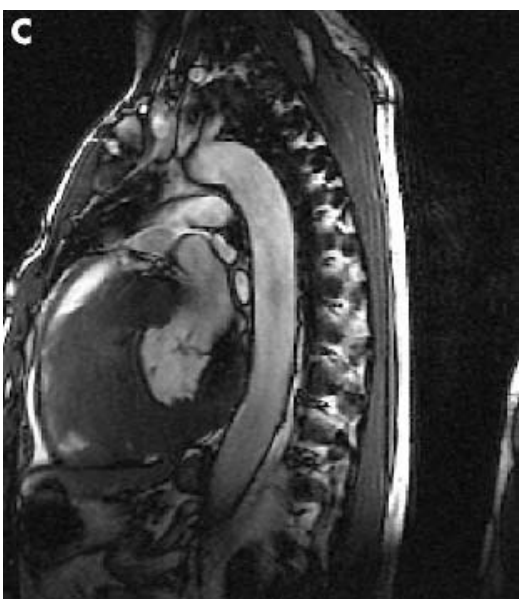

